\title{
MANAGING MORALE ON THE \\ BATTLEFIELD: A PSYCHOLOGICAL \\ PERSPECTIVE
}

\author{
MC van 't Wout \\ South African National Defence Force \\ GAJ van Dyk \\ Stellenbosch University
}

\begin{abstract}
From historical writings to current day, morale has always been regarded as a major determinant of success on the battlefield. The management of morale is thus also important in the South African National Defence Force (SANDF) for ensuring combat readiness. Numerous studies have been done in the past in various countries to investigate the factors influencing morale. A summary of the factors identified in the literature was used in the study on which this article is based, to compile a psychological plan to manage morale on the battlefield. Some recommendations for possible actions toward improving morale are included.
\end{abstract}

\section{Introduction}

Since medieval times and Sun Tzu's writings well over two thousand years ago, many things have changed in how wars are fought, but just as many things have remained the same. In the current South African National Defence Force (SANDF), some aspects of military life are so ingrained in military culture that the purpose thereof has been forgotten and thus neglected. Examples of such aspects are marching, show of respect and saluting, strict discipline, teaching uniformity of behaviour such as wearing of uniforms and even physical training.

Humans are subject to a dichotomy between individualisation and wanting to belong to a group - the need for inclusion and the need for differentiation. ${ }^{1}$ In the military environment, it is important for all to have a strong group feeling in order to

Scientia Militaria, South African Journal of Military Studies, Vol 43, No. 1, 2015, pp. 127-148. doi : $10.5787 / 42-1-1112$ achieve military objectives. Having soldiers train together, live together, wear the same clothes and talk and behave in the same way, teaches them to elevate the objectives of the group above their individual needs. The aim of 
physical fitness, as an example, is of utmost importance as it promotes the health and mental well-being of a person, relieves stress, improves resilience and enables soldiers to endure the physical hardships of combat. Most aspects of the military environment thus have a specific aim.

The study on which this article reports, investigated one such aim of military force preparation, viz. maintaining high morale in order to ensure combat readiness. Military and political leaders around the world regard high morale of the armed forces as one of the military's highest priorities. This includes high morale and mental well-being of the individual soldier, the military unit as well as the armed force as a whole. ${ }^{2}$ It is thus assumed that the morale of the members of the SANDF should also have high priority and receive ample attention.

\section{Defining morale}

It is apparent from the literature that the definition of morale differs between sources according to the emphasis placed on different aspects thereof. Some sources state that 'morale' is a synonym for unit cohesion or esprit de corps. ${ }^{3}$ This is, however, not the case as will be clarified in a later section of this article. It would also seem that the term 'morale' has different meanings in different contexts, e.g. industrial, educational, medical and military. ${ }^{4}$ The present research however focused on the definitions for the military context.

Manning defines morale as "... the enthusiasm and persistence with which a member of a group engages in the prescribed activities of that group". 5 Britt and Dickenson cite another definition, namely "psychological state of mind, characterised by a sense of well-being based on confidence in the self and in primary groups". ${ }^{6}$ The US Army Field Manual on Leadership defines morale as “... the mental, emotional, and spiritual state of the individual". ${ }^{7}$ In the present research, the following definition for morale was adopted: morale is a confident and positive state of mind of an individual and the persistent motivation (a willingness) to engage in the shared purpose of the group, especially when faced with challenging conditions (such as military operations).

\section{Factors influencing morale}

Spear initially identified two hundred factors affecting morale of soldiers, but after conducting a study whereby United Kingdom soldiers returning from combat were interviewed on this topic, these factors were summarised into five top- 
level factors. ${ }^{8}$ Other authors have also identified numerous factors influencing morale in a similar manner. ${ }^{9}$

\begin{tabular}{|c|c|c|c|}
\hline Reference & $\begin{array}{l}\text { Factors } \\
\text { influencing morale }\end{array}$ & Reference & Factors influencing morale \\
\hline $\begin{array}{l}\text { Adler, Bliese } \\
\text { and Castro } \\
(2011) \\
\end{array}$ & $\begin{array}{l}\text { Patriotism } \\
\text { Pride } \\
\text { Good leadership, etc. }\end{array}$ & $\begin{array}{l}\text { Manning } \\
\text { (1991) }\end{array}$ & $\begin{array}{l}\text { Cohesion } \\
\text { Esprit de corps } \\
\text { Leaders, etc. }\end{array}$ \\
\hline $\begin{array}{l}\text { Baron and } \\
\text { Kerr (2003) }\end{array}$ & $\begin{array}{l}\text { Social support } \\
\text { Primary group } \\
\text { Confidence, etc. }\end{array}$ & $\begin{array}{l}\text { NATO cited } \\
\text { in Zelenkov } \\
(2001)\end{array}$ & $\begin{array}{l}\text { Professional individual training } \\
\text { and aspiration to improve } \\
\text { Loyalty to country, etc. }\end{array}$ \\
\hline $\begin{array}{l}\text { Bester and } \\
\text { Stanz (2007) }\end{array}$ & $\begin{array}{l}\text { Cohesion (horizontal } \\
\text { and vertical), etc. }\end{array}$ & Shalit (1988) & $\begin{array}{l}\text { Leadership } \\
\text { Knowledge of the enemy, etc. }\end{array}$ \\
\hline $\begin{array}{l}\text { Brewer } \\
(2003)\end{array}$ & $\begin{array}{l}\text { A primary group } \\
\text { (familiarity with } \\
\text { others) } \\
\text { Group goal, etc. }\end{array}$ & $\begin{array}{l}\text { Shamir } \\
(2000) \text { cited } \\
\text { in Bester and } \\
\text { Stanz (2007) }\end{array}$ & Perceived combat readiness \\
\hline Gal (1986) & $\begin{array}{l}\text { Confidence in } \\
\text { immediate and senior } \\
\text { commanders } \\
\text { Confidence in oneself, } \\
\text { team and weapons, } \\
\text { etc. }\end{array}$ & Spear (2009) & $\begin{array}{l}\text { Leadership } \\
\text { Stressors } \\
\text { (physiological \& } \\
\text { psychological), etc. }\end{array}$ \\
\hline $\begin{array}{l}\text { Gilmore } \\
(2000)\end{array}$ & $\begin{array}{l}\text { Quality of weaponry } \\
\text { one depends upon for } \\
\text { survival } \\
\text { Medical care, etc. }\end{array}$ & $\begin{array}{l}\text { Taw, } \\
\text { Persselin and } \\
\text { Leed (1998) }\end{array}$ & $\begin{array}{l}\text { Preparedness } \\
\text { Resilience } \\
\text { Discipline }\end{array}$ \\
\hline Kott (2008) & $\begin{array}{l}\text { Mutual confidence } \\
\text { between leaders and } \\
\text { subordinates } \\
\text { Motivational } \\
\text { leadership } \\
\end{array}$ & $\begin{array}{l}\text { Zelenkov } \\
(2001)\end{array}$ & $\begin{array}{l}\text { Discipline } \\
\text { Sense of commitment } \\
\text { Self-control, etc. }\end{array}$ \\
\hline $\begin{array}{l}\text { Mastroianni, } \\
\text { Palmer, } \\
\text { Penetar and } \\
\text { Tepe }(2011)\end{array}$ & $\begin{array}{l}\text { Leadership that } \\
\text { promotes unit } \\
\text { cohesion } \\
\text { Goal-oriented, etc. }\end{array}$ & & \\
\hline
\end{tabular}

Table 1: Factors influencing morale listed per reference

It would seem that these factors, identified by different researchers, vary according to the context, i.e. the specific operation (time, place and conditions). These factors are listed in Table 1 per reference and were summarised into the most significant influencing factors for discussion in this research. Table 2 lists the factors having a negative influence on morale, and Table 3 lists consequences or effects of low morale. 


\begin{tabular}{|l|l|}
\hline Reference & Factors identified as influencing morale negatively \\
\hline Van Dyk (2009) & $\begin{array}{l}\text { Flow of information (communication) } \\
\text { Uncertainty about current and future situation } \\
\text { Family separation } \\
\text { Clear understanding of the reasons and the outcome of the mission or } \\
\text { uncertainty and confusion about the mission } \\
\text { Crowded conditions/lack of privacy } \\
\text { Insufficient ablution facilities } \\
\text { Heavy workload and long hours }\end{array}$ \\
\hline Oelenkov (2001) & $\begin{array}{l}\text { Overemphasis on material incentives } \\
\text { Disrespect for the enemy } \\
\text { Overestimating one's strength } \\
\text { Oversensitivity to absence of creature comforts } \\
\text { Combat failures/loss of initiative in combat } \\
\text { Racial prejudice } \\
\text { Extreme forms of individualism } \\
\text { Careerism } \\
\text { Tension in interpersonal relationships } \\
\text { Alcohol and drug abuse } \\
\text { Sexual harassment } \\
\text { Sexual perversion } \\
\text { Lack of physical exercise } \\
\text { Boredom }\end{array}$ \\
\hline $\begin{array}{l}\text { Practical, everyday matters of survival and personal well-being } \\
\text { In wartime - defeat in combat } \\
\text { Accommodation } \\
\text { Availability of food, ammunition and other supplies }\end{array}$ \\
\hline
\end{tabular}

Table 2: Factors that influence morale negatively

The commonalities in the factors listed in Table 1 and Table 2 have led to the identification of eight factors influencing morale. These are briefly discussed below. For the purpose of this research, the factors are only discussed in terms of their effect on the morale of soldiers. 


\begin{tabular}{|l|l|}
\hline Reference & Consequences of low morale \\
\hline Van Dyk (2009) & $\begin{array}{l}\text { Low levels of concentration and motivation } \\
\text { Higher probability of shooting and vehicle accidents } \\
\text { Alcohol and drug abuse } \\
\text { Conflict between leaders and subordinates and thus loss of cohesion } \\
\text { Loss of interest in the operation } \\
\text { Loss of respect for leadership }\end{array}$ \\
\hline Manning (1991) & $\begin{array}{l}\text { Stress casualties } \\
\text { Disciplinary problems } \\
\text { Attempts to leave the unit (during deployments) } \\
\text { Absence from work (including higher rates in sick reporting) } \\
\text { Neglecting of general appearance and physical fitness } \\
\text { Neglecting maintenance of equipment } \\
\text { Little confidence in self and organisation }\end{array}$ \\
\hline $\begin{array}{l}\text { Mastroianni et al. } \\
\text { (2011) }\end{array}$ & $\begin{array}{l}\text { Gissions will fail } \\
\text { Table } 3: \text { Thesion will wither }\end{array}$ \\
\hline
\end{tabular}

Table 3: The effects of low morale

\section{Cohesion}

Cohesion is a very important contributor to morale rather than a synonym or related but independent concept. ${ }^{10}$ It is also described as being a staple of military doctrine for over 2500 years. ${ }^{11}$ Becker defines cohesion as "... the binding of the group as an entity into a sense of 'we-ness' (a group identity), producing a sense of affiliation. It is an indicator of a positive group experience ..."12

Similarly, Bester and Stanz define it as “... the lateral and vertical person-toperson bonding within the primary groups of soldiers in a particular unit ..." where 'lateral' refers to peers and 'vertical' to leader-subordinate bonding". ${ }^{13}$ In some of the literature on combat readiness, the term 'social support' is used as a synonym for cohesion. $^{14}$

Cohesion is built on trust, respect and friendship. ${ }^{15}$ Social support is described as the soothing influence of friends, family and acquaintances - the primary group. Cohesion can be offered in the form of advice, material assistance, love, respect, acceptance or emotional support. ${ }^{16}$ Social support minimises the effect of other stressors thus ensuring the positive state of mind and persistent motivation to engage in the shared purpose of the group (morale). When accepted by the group, the soldier is more likely to feel important, worthy and loved, and the subsequent result is a more optimistic, confident soldier who is able to adjust to a stressful 
environment. ${ }^{17}$ The opposite is also true: a lack of familiarity with others can breed hostility and contempt. ${ }^{18}$ In a study on the most frightening aspects of war conducted among Israeli soldiers in 1974, Shalit found that the fear of harm or death was rated far less important than the fear of letting others down. ${ }^{19}$

From the discussion above, it would seem that cohesion is the most significant factor influencing morale. It is, however, not the only factor as will be illustrated in the discussions to follow.

Esprit de corps

Esprit de corps is defined as “... the bonding between soldiers and their secondary groups - beyond primary group bonding. Esprit de corps relates the soldier to the institution or the unit ... ${ }^{20}$ It is thus a positive feeling towards being associated with the secondary group, such as the SANDF. The soldier needs to be proud of the institution or organisation to which he or she belongs and be able to identify with the organisation. Manning argues that the method tried and tested for centuries of having regimental traditions such as distinctive names, colours (flags), messes and dress, as well as museums, bands and veterans associations contributes to linking the soldier's self-esteem to the reputation and expectations of the regiment. He further warns that attempts to replace these age-old customs with less expensive modern centralised practices borrowed from contemporary business will result in little to no success for military esprit de corps. ${ }^{21}$ As mentioned previously, esprit de corps is part of what makes a soldier continue in battle and strive towards reaching the objectives of the organisation.

Leadership

Leaders who can inspire, motivate and sustain the morale of others are at the core of an effective military force. A good leader can strengthen the dedication to a mission and the sense of purpose of the unit by demonstrating determined performance under pressure. ${ }^{22}$ It is also important for a leader to be someone with whom others would be proud to be affiliated. This implies that a leader's physical appearance and skills as well as technical and interpersonal skills should be of a very high standard. ${ }^{23}$ Brooks explains that people are 'social animals' who have a need for affection and affiliation and that the more secure a person feels 'at home', the more likely he/she is to venture out boldly. ${ }^{24}$ Security and a sense of belonging and worth facilitated by good leadership thus foster self-confidence, which is a very important characteristic of a soldier. ${ }^{25}$ 
Leaders of the primary group have a heavy responsibility to strike the perfect balance between instilling discipline and respect for the military hierarchy on the one hand, and bestowing a sense of kinship, caring, appreciation of the soldiers' skill and worth and personal loyalty on the other. Leadership also has a major influence on all of the other factors influencing morale. Leaders should thus adopt a leadership style and conduct activities that promote unit cohesion and strong morale. $^{26}$ They should also project confidence and commitment to a larger purpose. $^{27}$

Shared purpose/common goal

Individuals act differently when in contact with other humans as they would have acted when on their own. Humans are 'excited' by the presence of other humans. Close proximity alone, however, does not constitute a group, whilst a common goal does. ${ }^{28}$ Being part of a group with a specific task means that people will interact with and influence one another, thus perceiving themselves to be a group with a shared purpose and shared fate. ${ }^{29}$ Having a common goal thus builds group cohesion and subsequently increases morale. ${ }^{30}$

Knowing the purpose or goal of something builds motivation for specific behaviour. ${ }^{31}$ Performing tasks blindly without knowing the goal or significance leads to boredom and little satisfaction in a sense of purpose. For a defence force to be effective, its soldiers must thus know and understand the purpose of the organisation as well as their own specific goal and role within the larger mission. ${ }^{32}$ Each soldier must be convinced of a need to fight. ${ }^{33}$ When the primary group falls away, believing in the cause for which one is fighting is what keeps the soldier in battle. ${ }^{34}$ This implies that a shared purpose and believing in the cause for which one is fighting is the second most significant factor after cohesion affecting morale.

\section{Resilience}

Resilience has a bearing on morale, especially in terms of the motivation to persist amidst challenging circumstances. Resilience is defined as “... the ability to recover from or adjust easily to misfortune or change ..."35 Resilience thus refers to the ability of an individual to cope in difficult situations. Resilient people experience more hope, positivism and optimism overall and are thus better able to cope with demands (are able to get through tough times). Resilient people are also able to learn new skills and knowledge, and are less likely to become mentally or physically ill during adversity. It is good to note that resilience can be enhanced and developed to achieve benefits for both the individual and the organisation. ${ }^{36}$ Successful coping 
with adversity results in enhanced resilience, which in turn enables better coping with future adversity. Dealing with things that cause stress during training is thus a way to develop resilience. This is a quality which is needed by soldiers in order to cope during military operations.

There is also a link between good leadership and coping skills; thus, increasing resilience. If a leader can guide his/her unit through challenging situations, the achievement of overcoming such challenge builds the resilience of the individual. ${ }^{37}$ Resilience is also associated with the trait of ego strength. ${ }^{38}$ Some individuals already possess resilience when joining the defence force due to life experiences whilst growing up. Other individuals thus have a poorer coping and adjusting potential than others. ${ }^{39}$ Military psychologists can play a role in the process of selection of personnel for specific functions in the military by psychometric assessments to determine their resilience (or ego strength).

Preparedness and training

Building skill is the key to building morale. Having confidence in the skills of self and others builds confidence. Training thus has a central role in morale. ${ }^{40} \mathrm{As}$ stated in the introduction, military training aims to prepare soldiers for battle. Skills such as shooting and handling of military equipment alone would not succeed in preparing soldiers for military missions. Shay states that excellent training engages the whole person. ${ }^{41}$ This includes mind, body, emotions, character and spirit. Training has to prepare the soldier for the demands and stresses of war, and must therefore be tough and realistic at all levels. Below, some elements of military training and the aims thereof are discussed in brief.

Drills are taught in order to strengthen confidence by eliminating uncertainty of actions. During adverse situations of battle, there is no time for debate and problem solving; decisive and quick action is required. Marching teaches uniformity and following orders, improves physical fitness and endurance, as well as perseverance in tedious and less favourable situations. Furthermore, learning to move as one is a way of developing cohesion. Physical fitness is also an important element of military training as it contributes towards physical and mental well-being - being better able to withstand physical and mental stress. ${ }^{42}$ As with marching, physical fitness training in the military is done in groups, usually with simultaneous actions in response to the orders of the instructor. The latter has the same aims as those previously mentioned for marching.

Most military courses in the SANDF usually include some element of placing pressure on the student, such as receiving tasks after hours and demanding 
results that are close to impossible. These situations usually include little time to sleep. Such methods serve to develop resilience or coping skills. In leadership training, it is also a way to determine which individuals function well continuously during challenging conditions.

Fear of the unknown results in a lack of confidence. Soldiers need to be prepared for each mission. As stated above, soldiers have to understand the shared purpose of their unit (and organisation). Furthermore, if soldiers understand the purpose of the specific elements of their training and operations, it will lead to more confidence and subsequently higher morale and better performance. Pre-deployment training (or mission-ready training) is aimed at preparing forces for a specific mission. In many military forces today, peacekeeping operation (PSO) deployments are made up of groups of soldiers who do not necessarily come from the same training unit or home base. ${ }^{43}$ Pre-deployment training thus attempts to build group cohesion and morale amongst the soldiers who have to live and work together for months to come.

Discipline

One of the important factors in the preparation for deployment is discipline. Discipline builds self-respect and self-confidence. Soldiers operate in groups requiring close cooperation, and this necessitates mutual trust and respect. Discipline is a way to establish and maintain such trust and respect amongst one another as it shows consideration for others. Military discipline is also directed at teaching uniformity - promoting cooperation and decreasing individuality and, most importantly, inculcating resistance to fear. ${ }^{44}$ Discipline is thus also a contributor to unit cohesion and esprit de corps. Adhering to the standards, processes and traditions of the defence force shows evidence of commitment to the organisation. ${ }^{45}$

Working conditions

The military environment is characterised by challenging conditions. 'Battle fatigue' is a term often used to describe the point where a person's physical and emotional resources for coping with the stressors of war are depleted. ${ }^{46}$ Prolonged adverse conditions thus have a negative effect on morale. Such adverse conditions include elements such as dust, noise, harsh weather, lack of food and water and sleep deprivation. Van Dyk found that crowded conditions or lack of privacy, insufficient ablution facilities, heavy workload and long hours are among the major operational stressors for SANDF soldiers in PSOs. ${ }^{47}$ Operational planning and control should thus include attempts to minimise adverse working conditions. 


\section{Factors regarding the enemy that influence morale}

Knowing your enemy is also one of the foremost principles taught in the military. Apart from the factors described above, there are also factors regarding the enemy that have an effect on morale.

The presence of an enemy

An enemy is defined as "an opponent perceived to be behaving in a mode that actually threatens our aims. An enemy actively challenges our desired state or actions, and his gain is perceived to be our loss". ${ }^{48}$ The presence of an enemy with hostile intent creates a shared purpose and thus a strong pressure to unite. It thus has a positive influence on levels of morale. ${ }^{49}$

The capabilities of the enemy

The capabilities of the enemy, such as their weaponry, training, strength, ORBAT (Order of Battle) and efficiency (record of previous successes) could have a negative effect on morale. Nkewu and Van Dyk also list characteristics of the enemy, such as their level of morale, doctrine and tactics, leadership, ability to achieve surprise on own forces, logistical support and the attitude of the local population towards the enemy. ${ }^{50}$ If the enemy is perceived to be stronger than own forces, soldiers may perceive the battle to be futile and lack the motivation to engage in the objectives of the organisation.

Defeat in battle

This is one of the greatest morale-breaking factors in war. Such defeat usually includes some casualties and thus the loss of members of the primary group. This has a major traumatic influence on soldiers, and the positive state of mind and motivation to persist dissipates. ${ }^{51}$ 
No belief in the purpose of the mission

Another problematic situation in war occurs when the enemy identified by the political leaders of the state is not perceived as the enemy by the soldiers in battle. In the Vietnam War, this was a major problem. As anti-war sentiments in the United States grew, US troops' morale dropped dramatically, even to the extent where they referred to themselves by the initials UUUU - the unwilling, led by the unqualified, doing the unnecessary for the ungrateful. ${ }^{52}$

Enemy psychological operations (PsyOps)

The PsyOps potential of the enemy will also have a bearing on own forces' morale. Enemy capabilities and modus operandi in this regard must also be considered, as well as how to counteract it. ${ }^{53}$

Although these factors regarding the enemy may have a serious effect, the relationship with the primary group is still regarded as being more important than the enemy for the maintenance of morale. ${ }^{54}$ This relationship implies that people are more motivated to do good for those whom they value than to harm those who oppose them.

Alternative factors in complex peacekeeping operations influence morale

The International Applied Military Psychology Symposium in 2000 in Croatia focused on alternative factors involved in complex peacekeeping operations that possibly influence morale, other than the above-mentioned. In this regard, Adler, Dolan, Bienvenue and Castro ${ }^{55}$ focus on the peacekeeping forces' interaction and experiences in Kosovo. They mention factors like possibly being taken hostage, seeing dead bodies and body parts of women, children, own forces, smelling the stench of decomposing bodies, seeing poverty and children who are victims of war and dealing with hostile reactions from civilians. Figure 1 illustrated the most factors that will possibly influence the need for a psychological plan to sustain morale during different phases of an operation. 


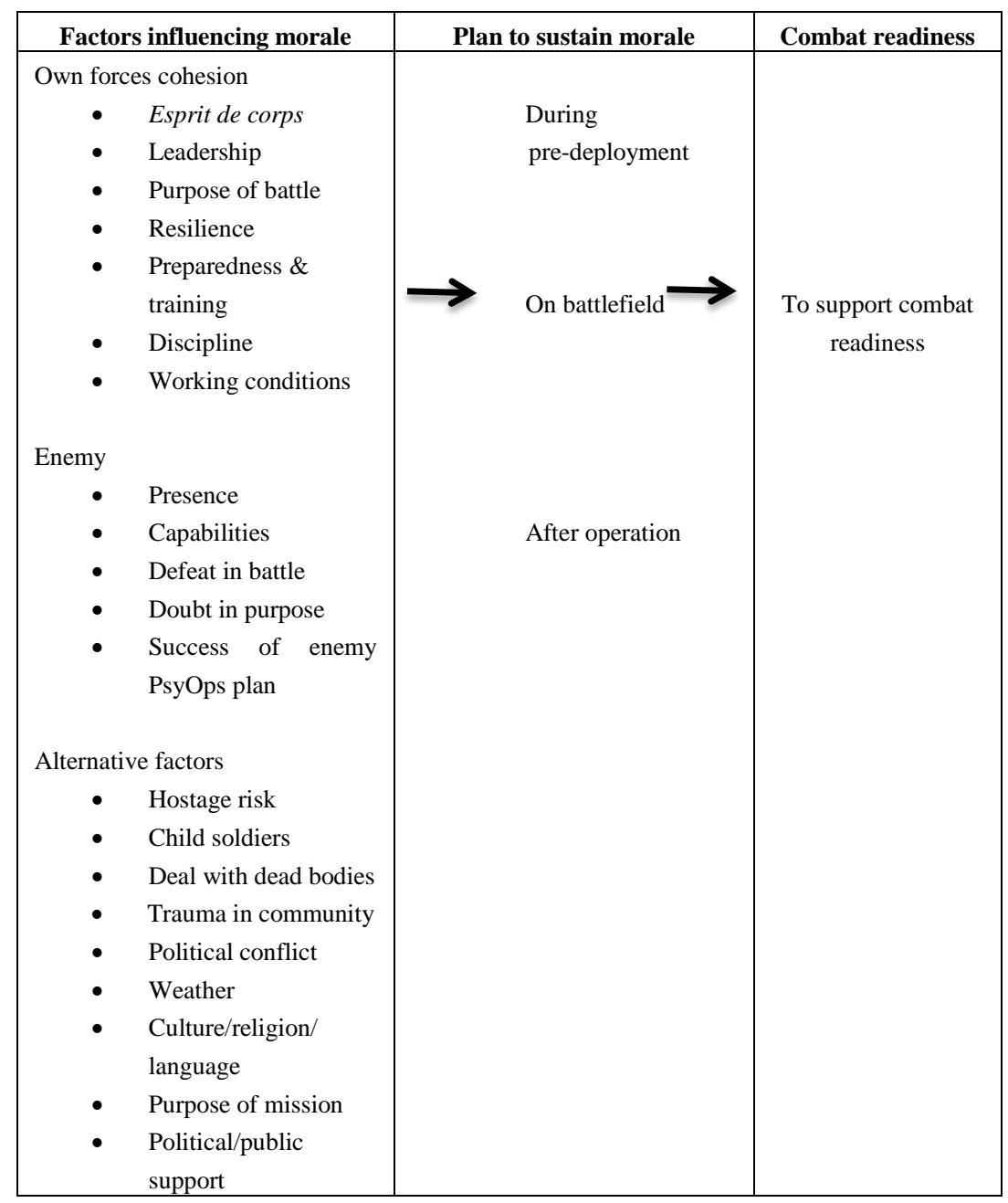

Figure 1: Conceptual framework to sustain morale

Shinga and Van Dyk ${ }^{56}$ explain factors involved for soldiers of the SANDF in (South) Sudan. They mention challenges in the internal politics (cross-border arrangements, Nile Water conflict, oil, etc.) between the two countries, also in-house conflict separately in Sudan and (South) Sudan, unfinished business between the two presidents and, lastly, unknown circumstances for the South Africans, like the 
desert, hot weather, strict religion, cultural and gender issues in the population. To deal with these could influence the morale of the member.

Lastly, during the Battle of Banqui, Central African Republic (CAR), South African soldiers were confronted with several factors that could influence their morale over time. Esterhuyse ${ }^{57}$ writes, "military force should only be used in support of national interests" while there are indications, according to Myburgh, ${ }^{58}$ that the mission instructions change from training members of CAR forces, protecting South African property and lastly protecting civilians, but ending up in a total war with 13 soldiers dead and possibly 27 injured. Scholtz ${ }^{59}$ analysed the Battle of Banqui and mentions that South Africa did not learn from the experiences of the peacekeeping mission in Bosnia, Kosovo and Lebanon. He comes to the conclusion that the South African troops were, like the Americans in Somalia, without a possible political and military strategy. In this regard, there was no withdrawal strategy and also no air ability to withdraw. Furthermore, our soldiers were confronted with child soldiers, not equipped with the necessary equipment and not supported by proper medical and air support during the operation. Cahill ${ }^{60}$ argues that public and political support and clear goals for a military mission prior to deployment are important to prevent another Vietnam experience. The politics accompanying a peacekeeping mission such as in (South) Sudan, DRC, CAR and the possible siding with a government or rebel group put the military goal/purpose of the mission for soldiers under pressure.

It is evident from the discussions above that the factors of the combat environment and the enemy influence the morale of soldiers and subsequently have an effect on the success of operations. It is thus of great importance to address these factors during deployments. The best way of addressing these factors would be to manage it with a psychological plan for operations.

\section{A need for a psychological plan to manage morale}

At present, no official framework for a psychological plan exists for the SANDF during operations. ${ }^{61}$ Van Dyk advocates the application of doctrine in line with international practice in Canada and the USA to develop a psychological plan for each operation in order to manage the mental health of deployed soldiers. ${ }^{62}$ The psychological plan for a mission in the SANDF would thus be a support plan included in the campaign planning process of the SANDF.

In planning for operations, the SANDF follows a planning model known as an 'appreciation', which results in a support plan to be submitted to the commander of a mission. Once approved, the senior staff officers appointed for this specific role, must coordinate and control the execution of the plan during the operation. A 
psychological plan for the management of morale of SANDF soldiers during an operation will be the responsibility of the military psychologist(s).

The military appreciation consists of an analysis of a set of factors (Figure 1) identified as relevant for the specific mission of the SANDF. The military psychologist must appreciate factors within the current context of an operation and plan accordingly. The aim of the analysis of the factors is to determine what the current state of that factor is within the SANDF, and how the influence of the battlefield characteristics during each stage of the operation might affect the level of morale, which in turn will influence the achievement of the operational end state. The effect of political, economic and social factors must also be considered for each morale factor. Furthermore, the analysis of each factor must be done in terms of implications, risks, required end-state and conclusions (i.e. what must be done). The factors should not be seen in isolation, but the dynamic interaction between them should be realised and kept in mind all the time. The appreciation is thus a framework to guide the military psychologist through the problem that needs to be solved, i.e. what is the specific situation during this mission and what will be the implications for the level of morale (or psychological well-being) of own forces, and what can be done to shield and protect own forces from negative influences on morale?

A proposed framework for a psychological plan focusing on the maintenance of high morale for SANDF soldiers during an operation is set out below.

\section{Framework for a psychological plan to manage morale on the battlefield}

This article first wants to discuss different dimensions in the process to sustain morale in a psychological plan for the battlefield. 


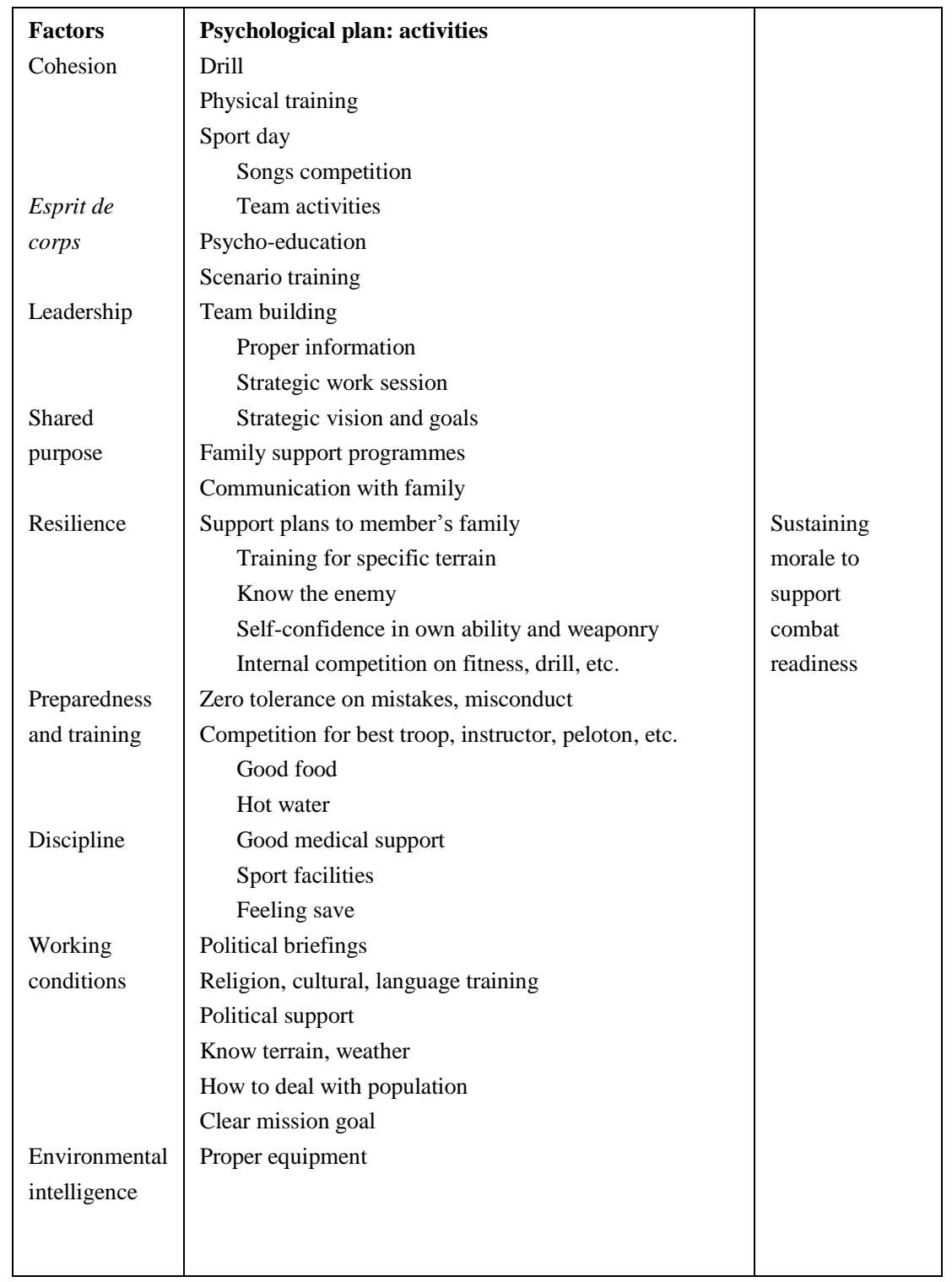

Figure 2: Actions to apply to sustain morale 
Multi-professional team (MPT) approach - to implement the psychological plan before, during and after the operation, the MPT psychologist, medical doctor, medical sister, social worker and chaplain need to be part of the process to evaluate levels of morale, share information, make proper individual, family and organisational diagnoses and develop proper plans to sustain morale. ${ }^{63}$

Strengthening morale - before, during and after the operation, the psychological plan needs to focus on support of group cohesion, esprit de corps and discipline to sustain the morale of the force - specifically after stressful periods of casualties. $^{64}$

Morale assessment and monitoring - it is imperative that part of the psychological plan be continuously assessed as it is necessary for management information for the commander to take the necessary steps to sustain high morale. In this regard, the MPT can play a vital role. ${ }^{65}$

Empowerment of leaders - leadership is one of the predictors of high morale. Several sources contribute to the empowerment role of leadership on morale on the battlefield, ${ }^{66}$ such as the positive contribution of the Big Five personality factors and hardiness on morale, ${ }^{67}$ the influence of transformational leadership to sustain morale ${ }^{68}$ and ways to reach leader success during operations. ${ }^{69}$

Empowerment of members with knowledge on the alternative factors soldiers need to be empowered on the internal political, cultural, religious and language challenges. They need proper information on terrain, weather, epidemics and health challenges. They also need political and public support for the operation with a clear goal. ${ }^{70}$

Support of family members and their relationships with members on the battlefield - the military unit and the family members need to be 'a new marriage' in other words, individuals and different systems need to support each other. ${ }^{71}$ The happier the unit-family marriage, the higher the sustainable morale and combat readiness of the unit and its soldiers. ${ }^{72}$

Mental hygiene - the concept of positive psychology ${ }^{73}$ is well known in psychology. 'Mental hygiene' refers to prevention of negative energy, destructive relationships and breakdown of morale, while wanting to create an atmosphere through supportive and healthy relationships to mobilise potential, activate positive energy, empower Ubuntu values and sustain high morale and combat readiness. 
Planned actions during different phases of the operation

Secondly, the article wants to explain examples of planned actions that can be applied during the process of the operation. Some actions can be specific to a particular phase, while other actions can be necessary in all the phases.

Actions during pre-deployment

The morale of the soldiers must be determined during the pre-deployment phase of the operation. The method for assessing this level of morale must be described, including the measuring instrument, groupings and timings.

Proposed interventions for the improvement of morale will then follow. This must include all the factors (see Figure 2). Specific interventions to be conducted focusing on factors in general or combinations of factors, and specifying possible extra interventions focusing on specific factor(s) should be emphasised.

Actions to implement on the battlefield

The morale of the soldiers must be determined on the battlefield. Target dates for such assessments as well as the method of assessment must be described (measuring instrument, groupings, timings). The military psychologist will inform the commander regarding the level of morale and its subsequent and/or possible effect on the operation. Interventions to improve or maintain morale will follow (see Figure 2).

Actions during de-mobilisation

The effect of the battlefield on the morale of the soldiers must be assessed and possible debriefings will follow to protect the mental health of the members. A detailed reintegration programme for homecoming must be developed by the MPT for members and their families over a weekend to facilitate resilience and success in the unit-family relationship.

\section{Conclusion}

From the above and in the military context, especially focusing on combat readiness, morale, unit cohesion, group loyalty and esprit de corps are terms 
describing related constructs to define effective functioning of military personnel. ${ }^{74}$ Changes in behaviour occur as a result of changes in morale. ${ }^{75}$ Such behavioural changes may be negative or positive, and could have a serious effect on operations. It is thus of paramount importance that morale be managed. Military leaders have long seen that high morale is the most important characteristic of successful fighting troops. The importance of planning for sustaining morale in the SANDF and the important role of the military psychologist should be noted.

The factors as discussed in this article are important for the maintenance of morale and should get attention at all times in the military environment, and not only during operations. From the discussions of each factor, it is evident that these factors are intertwined and mutually dependent. It is furthermore part of the building blocks of a defence force that cannot be put in place by a 'quick fix', but rather by properly planned and purposeful institutionalisation of standards, processes and traditions to ensure the development and maintenance of high morale.

Military training practices should be aimed at preparing soldiers for combat. This includes not only the acquisition of military skills, such as handling of weapons and military equipment or physical fitness, but also preparing soldiers psychologically for combat. The latter refers to the morale of soldiers as described in this article. Unfortunately, the purpose of different elements of military training is sometimes forgotten and/or neglected, and the mental well-being of own forces going into operations seems to hold a position low on the priority list for planning and preparation - not just on the side of military leaders, but also on the side of soldiers themselves.

It would seem that in the current SANDF the focus is primarily on being task-oriented and politically correct. Much time and budget are spent on equipment, management processes and personnel structures whilst team building, discipline, leadership and building the image of the SANDF, thus ensuring esprit de corps and better social support from the South African citizens, are neglected.

Planning for the sustainability of morale before, during and after operations is of paramount importance in the SANDF. The framework for a psychological plan to manage morale is the vehicle to empower the combat readiness of our forces and to guarantee success on the battlefield. 


\section{Endnotes}

${ }^{1}$ Brewer, MB. Intergroup relations ( $2^{\text {nd }}$ ed). Berkshire: Open University Press, 2003, 29; Brooks, D. The social animal: The hidden sources of love, character and achievement. New York: Random House, 2011, xvi.

${ }^{2}$ Zelenkov, MY. "Morale training in foreign armies". Military Thought 10/1. 2001. 76.

${ }^{3}$ Manning, FJ. "Morale, cohesion, and esprit de corps". In Gal, R \& Mangelsdorff, AD (eds), Handbook of military psychology, New York: Wiley, 1991, 456.

${ }^{4}$ Ibid., p. 454.

${ }^{5}$ Ibid., p. 455.

${ }^{6}$ Britt, TW \& Dickenson, JM. "Morale during military operations: A positive psychological approach". In Britt, TW, Adler, AB \& Castro, CA (eds), Military life: The psychology of serving in peace and combat, Westport: Praeger Security International, 2006, 158-181.

${ }^{7}$ US Army. "Military leadership". Field Manual 22-100. Washington, DC: US Government Printing Office, 1983, 228.

${ }^{8}$ Spear, L. "An initial conceptual model for morale factors". Paper presented at the $18^{\text {th }}$ Conference on Behaviour Representation in Modelling and Simulation, Sundance, 2009.

${ }^{9}$ Adler, AB, Bliese, PD \& Castro, CA. Deployment psychology: Evidence-based strategies to promote mental health in the military. Washington, DC: American Psychological Association, 2011; Baron, RS \& Kerr, NL. Group process, group decision, group action ( $\left.2^{\text {nd }} \mathrm{ed}\right)$. Berkshire: Open University Press, 2003; Bester, PC \& Stanz, KJ. "The conceptualisation and measurement of combat readiness for peace-support operations: An exploratory study". SA Journal of Industrial Psychology 33/3. 2007. 68-78; Brewer, MB. Intergroup relations ( $2^{\text {nd }}$ ed). Berkshire: Open University Press, 2003, 29; Gal, R. "Unit morale: From a theoretical puzzle to an empirical illustration: An Israeli example". Journal of Applied Social Psychology 16/6. 1986. 549-564; Gilmore, AB. You can't fight tanks with bayonets: Psychological warfare against the Japanese army in the South Pacific. Nebraska: University of Nebraska Press, 2000; Kott, A. Battle of cognition: The future information-rich warfare and the mind of the commander. Westport, PA: Praeger Security International, 2008; Manning op. cit.; Mastroianni, G, Palmer, B, Penetar, D \& Tepe, V. The warrior's guide to psychology and performance: What you should know about yourself and others. Washington, DC: Potomac Books, 2011; Shalit, B. The psychology of conflict and combat. New York: Praeger, 1988; Spear op. cit. ; 
Taw, JM, Persselin, D \& Leed, M. Meeting peace operations' requirements while maintaining MTW readiness. Santa Monica, CA: RAND, 1998; Zelenkov op. cit., pp. 76-85.

${ }^{10}$ Manning op. cit.

${ }^{11}$ Ibid., p. 455; Shay, J. Odysseus in America: Combat trauma and the trials of homecoming. New York: Scribner, 2002.

${ }^{12}$ Becker, L. Working with groups. Oxford: Oxford University Press, 2005, 39.

${ }^{13}$ Bester \& Stanz op. cit., pp. 68-78.

${ }^{14}$ Manning op. cit., p. 458.

${ }^{15}$ Rush, RS. "A different perspective: Cohesion, morale and operational effectiveness in the German Army, Fall 1944". Armed Forces and Society: AN Interdisciplinary Journal 25/3. 1991. 478.

${ }^{16}$ Baron \& Kerr op. cit., p. 178.

${ }^{17}$ Ibid., p. 180.

${ }^{18}$ Brewer, MB. Intergroup relations $\left(2^{\text {nd }}\right.$ ed). Berkshire: Open University Press, 2003, 88.

${ }^{19}$ Shalit op. cit.

${ }^{20}$ Bester \& Stanz op. cit., p. 71.

${ }^{21}$ Manning op. cit., p. 465.

${ }^{22}$ Mastroianni et al. op. cit., p. 122.

${ }^{23}$ Kott op. cit., p. 23.

${ }^{24}$ Brooks op. cit.

${ }^{25}$ Baron \& Kerr op. cit., p. 180.

${ }^{26}$ Mastroianni et al. op. cit., p. 72; Becker op. cit., p. 44.

${ }^{27}$ Ibid., p. 90.

${ }^{28}$ Baron \& Kerr op. cit., p. 21.

${ }^{29}$ Ibid.; Becker op. cit., p. 34, 67.

${ }^{30}$ Mastroianni et al. op. cit., p. 90.

${ }^{31}$ Becker op. cit., p. 77.

${ }^{32}$ Adler, Bliese \& Castro op. cit.; Manning op. cit.; Mastroianni et al. op. cit., p. 90.

${ }^{33}$ Shalit op. cit., p. 15.

${ }^{34}$ Manning op. cit., p. 465.

${ }^{35}$ Merriam-Webster. "Resilience". <http://www.merriamwebster.com/dictionery/resilience> Accessed on 11 February 2012.

${ }^{36}$ Warner, R. "Building personal resilience of staff to ensure successful organisational change". Management Today November 2011. 51-53.

37 Ibid.

${ }^{38}$ Volkman, M. "Resilience, defenses and case progress". Traumatic Incident 
Reduction Association News and Views Newsletter.

<http://www.tir.org/research_pub/art/resilience-defenses-cp.html> Accessed on 10 April 2012.

${ }^{39}$ Shalit op. cit., p. 15.

${ }^{40}$ Manning op. cit., pp. 463-464.

${ }^{41}$ Shay op. cit .

${ }^{42}$ Mastroianni et al. op. cit., p. 90.

43 Shay op. cit .

${ }^{44}$ Kott op. cit., p. 13.

45 Taw et al. op. cit.

${ }^{46}$ US Army. "Leaders' manual for combat stress control". Field Manual 22-51.

Washington, DC: US Government Printing Office, 1994.

${ }^{47}$ Van Dyk, GAJ. "The role of military psychology in peacekeeping operations: The South African National Defence Force as an example". Scientia Militaria 37/1. 2009. 113-135.

${ }^{48}$ Shalit op. cit., p. 84.

${ }^{49}$ Manning op. cit., p . 462.

${ }^{50}$ Nkewu, Z \& Van Dyk, GAJ. "A framework of a psychological plan for the battle: A proposal for discussion”. In Van Dyk, GAJ (ed), Strategic challenges for African armed forces for the next decade, Stellenbosch: Sun Press, 2008, 241-263.

${ }^{51}$ Manning op. cit .

52 Ibid.

${ }^{53}$ Nkewu \& Van Dyk op. cit., pp. 241-263.

${ }^{54}$ Manning op. cit.

55 Adler, A, Dolan, C, Bienvenue, R \& Castro, CA. "Soldier peacekeeping experiences and wellbeing after returning from deployment to Kotosvo". Paper delivered at the $36^{\text {th }}$ International Applied Military Psychology Symposium, Split, Croatia, 11 - 15 September 2000.

${ }^{56}$ Shinga, GM \& Van Dyk, GAJ. "Peacekeeping in (South) Sudan: A challenge for the South African National Defence Force". Journal of Contemporary African Studies (in publication process). 2014.

${ }^{57}$ Esterhuyse, A. "The politics of slain”. Rapport. 30 March 2013.

${ }^{58}$ Myburgh, PL. “Ons moes kinders skiet”. Rapport. 31 March 2013.

${ }^{59}$ Scholtz, L. "Leer uit ander se foute". Beeld. 26 March 2013.

${ }^{60}$ Cahill, MM. Morale: The mission principle of war. New Port, RI: Naval War College, 2000.

${ }^{61}$ Bester, PC. Personal communication, 22 March 2012. 
${ }^{62}$ Van Dyk op. cit., pp. 113-135.

${ }^{63}$ Dhadhla, TJ \& Van Dyk, GAJ. "Management of post-traumatic stress disorder in the military: An intervention model”. Journal of Psychology 19/4. 2009. 113-135.

${ }^{64}$ Britt \& Dickinson op. cit., pp. 157-184.

${ }^{65}$ Bliese, PD, Wright, KM \& Hoge, CW. "Preventive mental health screening in the military". In Adler, Bliese \& Castro op. cit., pp. 175-194.

${ }^{66}$ Glad, B (ed.). Psychological dimensions of war. New York: Sage, 1994, 45-90.

${ }^{67}$ Bartone, PT, Eid, J, Johnsen, BH, Laberg, JC \& Snook, SA. "Big five personality factors, hardiness and social judgement as predictors of leader performance". Leadership and Organization Development Journal 30/4. 2009. 498-521.

${ }^{68}$ Bass, BM, Avolio, BJ, Jung, DI \& Berson, Y. "Predicting unit performance of assessing transformational and transactional leadership". In Mathews, MD \& Laurence JH (eds), Military psychology (Vol 4), London: Sage, 2012, 21-45.

${ }^{69}$ Grundlingh, A \& Van Dyk, GAJ. Leader success in the military: A challenge for the $21^{\text {st }}$ century. Saarbrucken: Scholar Press, 2013, 100-110.

${ }^{70}$ Shinga \& Van Dyk op. cit.

${ }^{71}$ Kalamdien, DJ \& Van Dyk, GAJ. “A psychological support programme for peacekeeping soldiers and their families: A preliminary model". Journal of Psychology in Africa 19/2. 2009. 281-289.

${ }^{72}$ Wiens, TW \& Bois, P. "Maintaining family resilience before, during and after military separation". In Britt, TW, Castro, CA and Adler, AM (eds), Military life: The psychology of serving in peace and combat, London: Praeger Security International, 2006, 13-38.

${ }^{73}$ Antonovsky, A. Unravelling the mystery of health: How people manage stress and stay well. San Francisco, CA: Josey Bass, 1987, 25-45.

${ }^{74}$ Adler, Bliese \& Castro op. cit.

75 Spear, L. "An initial conceptual model for morale factors". Paper presented the $18^{\text {th }}$ Conference on Behaviour Representation in Modelling and Simulation, Sundance, 21 - 24 March 2009. 